\title{
PER
}

\section{MATHEMATICS ANXIETY AND MATHEMATICS BELIEFS AS CORRELATES OF EARLY CHILDHOOD PRE-SERVICE TEACHERS' NUMERACY SKILLS}

\author{
Oludola S. Sopekan, Adeneye O. A. Awofala
}

\begin{abstract}
The purpose of this study was to investigate mathematics anxiety and mathematics beliefs as correlates of early childhood pre-service teachers' numeracy skills in Nigeria. A crosssectional survey research design within quantitative methodology was adopted for the study involving 320 early childhood pre-service teachers from the University of Lagos. Three valid and reliable instruments were used for data collection and the collected data were analysed using mean, standard deviation, Pearson moment correlation and multiple regression analysis at 5\% level of significance. Results showed that the majority of the early childhood pre-service teachers had high mathematics anxiety and high mathematical beliefs. While mathematical beliefs had significant positive correlations with early childhood pre-service teachers' numeracy skills, mathematics anxiety had a negative correlation with numeracy skills. Mathematical beliefs were a good predictor of early childhood pre-service teachers' numeracy skills. Based on these findings it was concluded that early childhood teacher education programme should include strategies to eliminate mathematics anxiety and foster constructivist mathematical beliefs capable of promoting early childhood pre-service teachers' numeracy skills.
\end{abstract}

Keywords: Mathematics anxiety, mathematical beliefs, early childhood pre-service teachers, numeracy skills.

\section{Introduction}

Many countries of the world are increasingly putting more emphasis on early childhood education with attendant increase in the admission rates into kindergartens (Karatas, Guven, Öztürk, Arslan, \& Gürsoy, 2017). For instance, countries like United Kingdom, France, Belgium, and Norway have above $90 \%$ of age 3 children in preschools (OECD, 2015). These countries are not only preoccupied with evolving and maximizing educational programmes for their teeming population of young children but are also offering training programmes for preschool teachers and early childhood pre-service teachers (National Association for the Education of Young Children [NAEYC], 2001; OECD, 2011) to enable them function well in the kindergartens. As a mark of honour for the preschool, the National Council of Teachers of Mathematics [NCTM] (2000) incorporated it into the standards for school mathematics. This is done for two key reasons: First, exposing preschoolers to quality and meaningful mathematics at a very tender age may be one way to foster mathematical proficiency (Awofala, 2017) in them and get them ready for future mathematics at the primary school level. In this way difficulties arising from teaching and learning of mathematics at the other levels of education may be reduced to the barest minimum as the preschoolers would have gained conceptual understanding of the early mathematics which could serve as a strong foundation for future mathematics learning. Second, the extant literature revealed that preschoolers have natural curiosity for mathematics (Heinkle, 2000; Denton \& West, 2002) which when sustained could foster their informal mathematical skills and intuitive mathematical thinking in preparation for their future learning of mathematics at ease.

No doubt learning mathematical skills is an intricate endeavour that is not only intellectually challenging but emotionally puzzling. Mathematical skills are very important in everyday human endeavor and deficiencies in mathematical performance could lead to adverse eff ect in various spheres like education, 
daily routine and career. This effect can be seen in the area of not being able to make knowledgeable resolutions on monetary matters which could have a multiplier consequence on people's emotional and bodily well-being (Butterworth, 2010; Kucian \& von Aster, 2015; Paulos, 1988). Thus, making wellinformed decisions based on numerical abilities are fast becoming ubiquitous in our everyday life (Peters, Västfjäll, Slovic, Mertz, Mazzocco, \& Dickert, 2006) to the extent that possession of numeracy skills is commanding not only for an individual but for the society in general. Current developments have impacted on how to describe and characterize the concept of numeracy methodically (Cokely, Galesic, Schulz, Ghazal, \& Garcia-Retamero, 2012; Reyna, Nelson, Han, \& Dieckman, 2009; Schwartz, Woloshin, Black, \& Welch, 1997). Numeracy refers to the ability to comprehend, utilize, compute, deploy, deduce results, and converse mathematical facts (Awofala \& Anyikwa, 2014). Concerning the adult setting, numeracy denotes the practical or purposeful utilization of mathematics to the point of proficiency (Awofala \& Anyikwa, 2014; Awofala, 2017).

Nonetheless, it is quite disheartening to note that less than $40 \%$ of Nigerians are numerate with a very large percentage of the population suffering from innumeracy (Awofala \& Anyikwa, 2014). Unexpectedly in the developed countries such as the USA, large percentage of the adult population show lack of numerical skills in dealing with numbers (Peters, 2012) while in the United Kingdom roughly $25 \%$ of the population swim in the pool of innumeracy (Parsons \& Bynner, 2005). This high level of innumeracy in the world population is a threat to the socio-economic well-being of nations and the world at large (Butterworth, 2010). This low numeracy skill is not unconnected to individual showing undesirable attitudes and sentiments toward mathematics (Lake \& Kelly, 2014). These nerve-racking feelings toward mathematics (Awofala \& Awolola, 2011) seem to be common among early childhood pre-service teachers thereby causing severe anxiety, and consequently making them to shun the teaching of some mathematical concepts. The perturbing emotional variable which tends to hurt mathematics skills at the primary level is mathematics anxiety (Skagerlund, Östergren, Västfjäll, \& Träff, 2019). The extant literature has come up with diverse characterizations of mathematics anxiety, yet, common to most definitions is the resounding opinion that mathematics anxiety causes an adverse emotive reaction amidst some people (Awofala \& Odogwu, 2017; Suárez-Pellicioni, Núñez-Peña, \& Colomé, 2016). Mathematics anxiety is a performance-based anxiety disorder that involves physiological stimulation, negative cognitions, and avoidance behaviours that lead to an affective drop-in mathematics and mathematics-related activities (Awofala \& Odogwu, 2017). It is popular that mathematics anxiety produces a debilitating effect that seems to advance with age into adulthood. In essence, it is crucial to nurture a productive learning milieu in the preschool years so that children will not develop mathematics anxiety into adulthood. Evidence suggests that early childhood pre-service teachers can transfer their mathematics anxiety to their pupils (Awofala \& Akinoso, 2017) with its damaging and negative impact on mathematical performance well-researched and established (Awofala \& Odogwu, 2017; SuárezPellicioni, Núñez-Peña, \& Colomé, 2016). The precise mechanisms through which mathematics anxiety obstructs and affects numeracy skills in early childhood pre-service teachers stay unsettled. It has been established that not less than $11 \%$ of university students and $17 \%$ of the population have mathematics anxiety (Richardson \& Suinn, 1972; Aschraft, \& Moore, 2009). This high widespread rate is frightening noting the obstructive effect of mathematics anxiety on mathematical ability.

Several studies have identified causes of mathematics anxiety to include: undesirable attitude transfer from teachers, intellectual factors, and past failure in mathematics (Lindskog, Winman, \& Poom, 2017) in which mathematics anxiety inhibits, distort and deplete working memory resources that consequently hamper mathematical skills (Ashcraft \& Faust, 1994). Research has shown clearly that mathematics anxiety weakens number processing abilities (Lindskog, Winman, \& Poom, 2017; Maloney, Ansari, \& Fugelsang, 2011) but what is not clear is whether mathematics anxiety weakens the entire aspect of mathematics to the same level in early childhood pre-service teachers. One aspect of mathematical ability that is rarely researched concerning mathematics anxiety is numeracy (Skagerlund, Östergren, Västfjäll, \& Träff, 2019) and it is startlingly to note that little is well-known regarding the contrivances by which mathematics anxiety impact numeracy skills in early childhood pre-service teachers. This is one of the foci of the study and not forgetting the tendency for mathematics anxiety to have implications for early childhood preservice teacher practice in numeracy. While researchers have developed numeracy skill tests such as the Berlin Numeracy Test (Cokely et al, 2012) and the abbreviated numeracy test (Weller, Dieckmann, Tusler, Mertz, Burns, \& Peters, 2013) to assess adult numeracy, it 
remains to be understood how mathematics anxiety influences numeracy. Numeracy has been used to predict normative decision-making skills in adult (Skagerlund et al, 2019) and to measure risk associated with medical domain (Schwartz, Woloshin, Black, \& Welch, 1997).

The other focus of the present study is to examine mathematics beliefs as predictive of early childhood pre-service teachers' numeracy skills. Mathematics belief is acclaimed to be associated with teaching practice in mathematics (Aslan, Ogul, \& Tas, 2013) and is defined as individual verdicts and implicit norms and assumptions about the nature of mathematics and teaching and learning mathematics deduced from experiences (Kagan, 1992; Raymond, 1997). Mathematics belief has three key philosophical formations indicated as problem-solving, instrumentalist, and Platonist. In the Platonist formation of beliefs, mathematics is viewed as a static but unified body of certain rules. Instrumentalist sees mathematics as consisting of exact operation, rules and skills. The problem-solving dimension sees mathematics as a vigorous and ethnic production that can be cultivated with invention (Ernest, 1991). Teachers' activities in the classrooms are creations of their beliefs (Zakaria \& Maat, 2012) with an argument regarding the constancies amid teachers' practices and their beliefs. This issue is somehow complex as some authors have found consistency between teachers' beliefs and classroom practices (Peterson, Fennema, Carpenter \& Loef, 1989; Kupari, 2003), while other studies agreed to the contradictions between beliefs and practices (Brown, 1986; Beswick, 2005) in mathematics education. Teachers' mathematics beliefs are affected by prior experiences at school, teachers' present practice and teacher education courses (Raymond, 1993) in which teachers' beliefs influence students' learning of mathematics (Kagan, 1992) and consequently affect students' perceptions of mathematics (Yesil-Dagli, Lake \& Jones, 2010). A synthesis of literature regarding pre-service teachers' beliefs (Kane, Sandretto \& Heath, 2002) revealed that: students are admitted into teacher education programmes with prior beliefs which hinged on their past experiences at pre-tertiary levels; these beliefs are strong and resilient to alteration or modification; these beliefs serve as sifters to new knowledge, accommodating only what is harmonious with present beliefs; and beliefs are present in an inferred or hidden form and are arduous to communicate.

Mathematics teachers' beliefs have been found to affect students' achievement in mathematics (Aslan, Ogul, \& Tas, 2013) in which mathematics teachers who hold more traditional beliefs are more inclined to engage in traditional practices like performance and obtaining correct answers (Stipek, Givvin, Salmon \& MacGyvers, 2001). To date, no study had assessed the relation between early childhood preservice teachers' mathematics beliefs and their numeracy skills. Aslan et al (2013) found that elementary teachers' beliefs about mathematics had a significant influence on children's number and operation and geometric shapes achievement. The more confident teachers are not only in their knowledge of mathematics but also mathematical ability, the greater they prioritize the usefulness of teaching mathematics in preschool and early primary school (Geist, 2015).

In line with the review of related literature, it is noted that there is scarcity of studies concerning mathematics anxiety and mathematics beliefs as correlates of early childhood preservice teachers' numeracy skills. So this study investigated mathematics anxiety and mathematics beliefs as correlates of early childhood preservice teachers' numeracy skills in Nigeria.

\subsection{Purpose of the study}

The purpose of the present study was to investigate mathematics anxiety and mathematics beliefs as correlates of early childhood preservice teachers' numeracy skills in Nigeria.

\subsection{Research Questions}

Specifically in this study, the following research questions were addressed:

RQ1. What is the level of mathematics anxiety among Nigerian early childhood pre-service teachers?

RQ2. What is the level of mathematics beliefs among Nigerian early childhood pre-service teachers?

RQ3. What are the relationship between early childhood pre-service teachers' numeracy skills, beliefs about mathematics and mathematics anxiety? 
RQ4. What are the composite and relative contributions of each factor of beliefs about math (affective and behavioural engagement in mathematical learning, confidence and beliefs regarding one's personal competence in math, mathematical beliefs, and beliefs about mathematical problem solving) and each factor of mathematics anxiety (emotionality and worry) to the explanation of the variance in the early childhood pre-service teachers' numeracy skills?

\section{Methods}

The participants were 320 ( 84 males and 234 females) early childhood pre-service teachers at the University of Lagos, Nigeria. The ages of the pre-service teachers ranged from 19 to 30 years, with $80 \%$ of them 20 years or less and $20 \%$ between 21 and 30 years inclusive. This distribution of ages is characteristic of the University of Lagos early childhood teacher education intakes with high proportions of "recent school leavers". All of the participants had studied mathematics at the Senior Secondary School Certificate level in which mathematics is a cross-cutting core subject at this level in Nigeria. Three instruments namely: Numeracy Self-Assessment Questionnaire (NSAQ), Mathematics Anxiety Questionnaire (MAQ) and Mathematics Beliefs Questionnaire (MBQ) were administered during class time at the close of the respondents' last Montessori mathematics course in 2018. A cross-sectional survey research design within quantitative methodology was considered most apt for this study because it helped in collecting data at one point in time from a sample selected to represent a larger population (Owens, 2002). In general surveys are prevalent because of their flexibility, effectiveness and generalizability in tackling enormous challenges, and in particular when the objective is to describe the beliefs, viewpoints and perceptions of the participants. One major disadvantage of the survey is that it does not allow the investigator to dig deeper into issues as would be possible in an interview (Mertler \& Charles, 2005). In the present study, the NSAQ and MAQ had been validated for Nigerian use (Awofala \& Anyikwa, 2014; Awofala \& Akinoso, 2017) while the MBQ was adopted from GómezChacón and García-Madruga (2009).

All three questionnaires were trial tested with a smaller sample of early childhood pre-service teachers in a different university in south-west Nigeria earlier in 2018 and their Cronbach alpha coefficients were calculated as 0.85 for NSAQ, 0.86 for MAQ, and 0.82 for MBQ. According to the literature the NSAQ had three interpretable factor structure named as numeracy in everyday life, numeracy in workplace tasks, and numeracy in mathematical tasks (Awofala \& Anyikwa, 2014). The MAQ had two dimensions viz worry (Cronbach $\alpha=0.80$ ) and emotionality (Cronbach $\alpha=0.90$ ) (Awofala $\&$ Akinoso, 2017) while the MBQ had four factors namely: affective and behavioural engagement in mathematical learning (Cronbach $\alpha=0.85$ ), confidence and beliefs regarding one's personal competence in math (Cronbach $\alpha=0.86$ ), mathematical beliefs (Cronbach $\alpha=0.90$ ), and beliefs about mathematical problem solving (Cronbach $\alpha=0.82$ ). All the questionnaires employed Modified Likert Scales. The NSAQ consisted of 24 items while the MBQ contained 13 items to which the respondents were required to respond undecided- 0 , strongly agree- 4 , agree- 3 , disagree- 2 , and strongly disagree- 1 for positively worded statement while the reverse was the case for all negatively worded statement with undecided remaining as the starting point in both cases. The MAQ consisted of 11 items to which the participants were requested to respond Not at all -0 , A little -1 , A fair amount -2 , Much -3 and Very much -4 . Data collected with the questionnaires were summarized and analysed using frequency, percentage, mean, standard deviation, Pearson moment correlation, and multiple regression analysis.

\section{Results}

\subsection{Research Question One: What is the level of mathematics anxiety among Nigerian early childhood pre-service teachers?}

In the mathematics anxiety scale, the score ranged from 0 to 4 . A score of 2 is the middle point so higher scores indicate high mathematics anxiety. Of 320 early childhood pre-service teachers, $178(55.63 \%)$ had scores greater than $2(M=2.72, S D=0.50$, score range: $2.03-3.92,95 \% C I=2.64-2.79), 138(43.13 \%)$ had scores less than $2(M=1.33, S D=0.43$, score range: $0.20-1.98,95 \% C I=1.26-1.40)$, while $4(1.24 \%)$ had scores equaled $2(\mathrm{M}=2, \mathrm{SD}=0$, score range: $2.00,95 \% C I=2.00)$. A large proportion of these early childhood pre-service teachers had high mathematics anxiety. However, the overall $M=2.11, S D=0.83$, score range: $0.20-3.92$, and $95 \% C I=2.02-2.20$ for the entire sample showed high mathematics anxiety 
of early childhood pre-service teachers. Table 1 showed the descriptive statistics of the items in the MAQ. There were five items in the Emotionality subscale, and they talked about mathematics promoting being at ease and relax, mathematics test causing nervousness and uneasiness, mathematics test being scary, feeling dread, and feeling scared to take advanced mathematics. The means of the five items indicate that early childhood pre-service teachers' emotionality in mathematics was less than anticipated and this could impact their studying of mathematics.

Table 1 Descriptive statistics of MAQ items

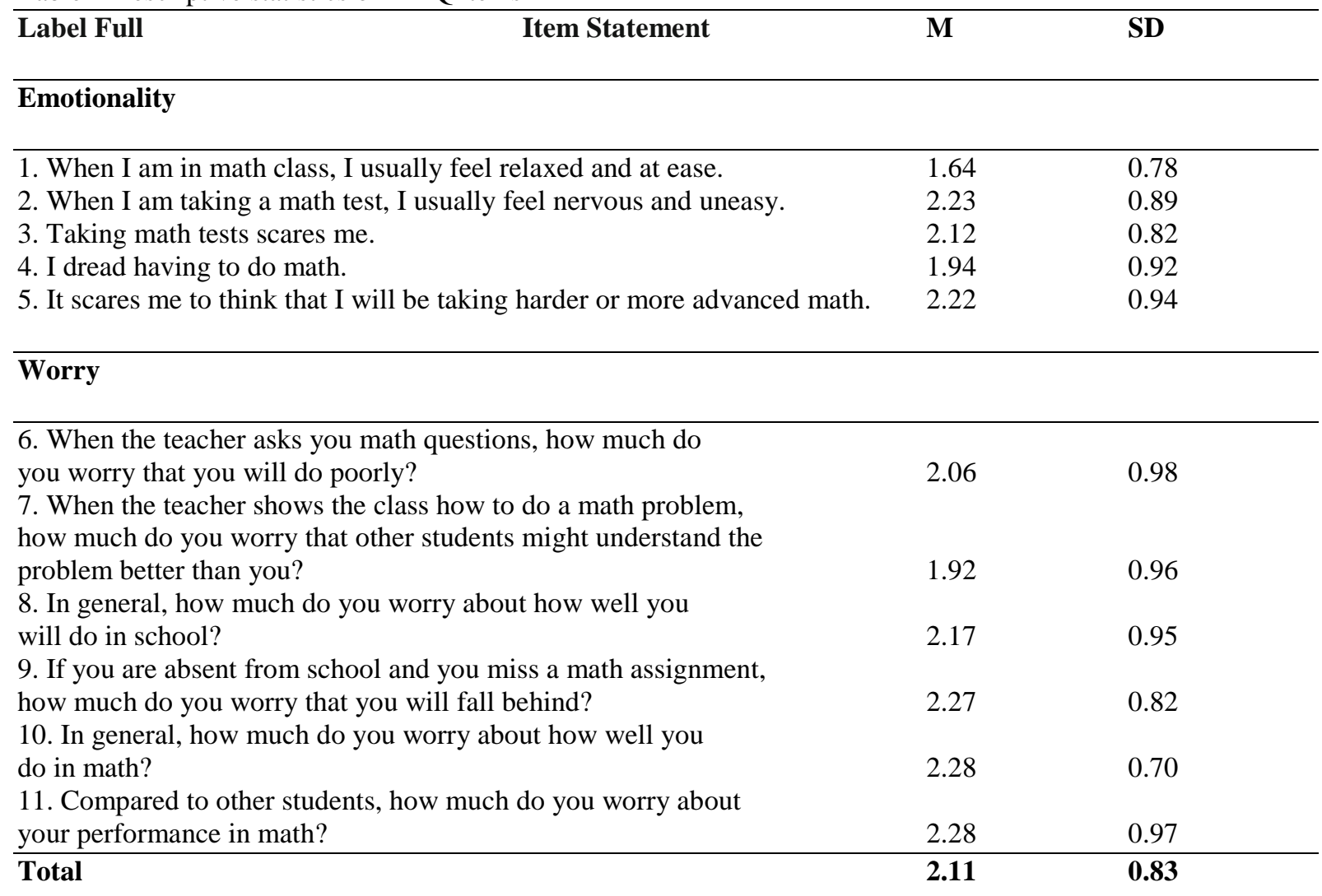

The six items in the Worry subscale talked about the degree of worry that one would do poorly in mathematics, the worry that colleagues would do better in mathematics than me, worrying about one's performance in school, worrying about falling behind in mathematics as a result of being absent from school, worrying about doing well in mathematics, and worrying about poor performance when compared one's result with colleagues.

\subsection{Research Question Two: What is the level of mathematics beliefs among Nigerian early childhood pre-service teachers?}

In the mathematical beliefs questionnaire, the score ranged from 0 to 4 . A score of 2 is the middle point so higher scores indicate high mathematical beliefs. Of 320 early childhood pre-service teachers, 292 $(91.25 \%)$ had scores greater than $2(M=2.89, S D=0.43$, score range: $2.06-3.77,95 \% C I=2.84-2.94), 26$ $(8.13 \%)$ had scores less than $2(M=1.68, S D=0.22$, score range: $1.15-1.96,95 \% C I=1.59-1.77)$, while 2 $(0.63 \%)$ had scores equaled $2(\mathrm{M}=2, \mathrm{SD}=0$, score range: $2.00,95 \% C I=2.00)$. A large proportion of these early childhood pre-service teachers had high mathematical beliefs. However, the overall $M=2.79$, $S D=0.53$, score range: $1.15-3.77$, and $95 \% C I=2.73-2.85$ for the entire sample showed high mathematical beliefs of early childhood pre-service teachers.

Table 2 showed the descriptive statistics of the items in the MBQ. There were three items in the Affective and behavioural engagement in mathematical learning subscale, and they talked about working hard in 
mathematics, making mistakes in mathematics and correcting them, and inventing new problems in mathematics. The means of the three items indicate that early childhood pre-service teachers' affective and behavioural engagement in mathematical learning was highly desirable and this could impact their studying of mathematics.

Table 2 Descriptive statistics of MBQ items

\begin{tabular}{lll}
\hline \multicolumn{1}{c}{ Label Full Statement } & M & SD \\
\hline Affective and behavioural engagement in Mathematical learning & & \\
& & 0.78 \\
\hline 1. I work hard in Math (subject). & 0.86 \\
2. If I make mistakes, I work to correct them. & 0.55 \\
3. I like to invent new problems. & 3.22 & 0.82 \\
\hline Confidence and beliefs regarding one's personal competence in math & 2.42 & 0.73 \\
4. I learn math quickly. & 2.53 & 0.92 \\
5. When I am asked to solve math problems, I get nervous. & 2.69 & 0.49 \\
6. I feel confident when I study or work on math. & 2.56 & 0.89 \\
7. I feel happy when I solve math problems. & 2.62 & 0.93 \\
\hline Mathematical Beliefs & 2.78 & 0.97 \\
8. Math allows us to understand the world we live in better. & 3.04 & 0.81 \\
9. Math consists of concepts and procedures that we have to memorize. & 2.85 & 0.82 \\
10. Everyone can learn math. & & 0.80 \\
\hline Beliefs about mathematical problem solving & 2.95 & $\mathbf{0 . 8 2}$ \\
11. When I cannot solve a math problem quickly, I keep on trying. & 2.86 & 2.46 \\
12. I prefer challenging tasks in order to learn new things. & $\mathbf{2 . 7 9}$ \\
13. Math should not place much importance on problem-solving. & & \\
\hline Total & & \\
\hline
\end{tabular}

The four items in the confidence and beliefs regarding one's personal competence in mathematics subscale talked about learning mathematics quickly, getting nervous when asked to solve mathematics problems, feeling confident when studying mathematics, and feeling happy when solving mathematics. The means of the four items show that early childhood pre-service teachers' confidence and beliefs regarding one's personal competence in mathematics was highly commendable and this could impact their studying of mathematics. The three items in the mathematical beliefs subscale talked about mathematics helping understand the world, mathematics consisting of concepts and procedures that one has to memorise, and that everyone can learn mathematics. The means of the three items show that early childhood pre-service teachers' mathematical beliefs was highly commendable and this could impact their studying of mathematics. Three items in the beliefs about mathematical problem-solving subscale talked about keeping on trying the mathematics problem that is proving difficult, preferring challenging tasks in mathematics to learn new things, and mathematics should not place much importance on problem-solving. The means of the three items indicate that early childhood pre-service teachers' beliefs about mathematical problem solving was highly commendable and this could impact their studying of mathematics.

\subsection{Research Question Three: What are the relationships among early childhood pre-service teachers' numeracy skills, beliefs about mathematics and mathematics anxiety?}

The results in Table 3 below showed the relationships among the numeracy skills, beliefs about mathematics and mathematics anxiety of early childhood pre-service teachers. Table 3 showed that there was a significant positive correlation between the early childhood pre-service teachers' total numeracy skills and numeracy in everyday tasks $(r=.76, p<.01)$, numeracy in workplace tasks $(r=.79, p<.01)$, numeracy in mathematical tasks $(r=.80, p<.01)$, affective and behavioural engagement in mathematical learning $(r=.37, p<.01)$, confidence and beliefs regarding one's personal competence in math $(r=.37$, $p<.01)$, mathematical beliefs $(r=.41, p<.01)$, beliefs about mathematical problem solving $(r=.28$, 
$p<.01)$, and mathematical beliefs total $(r=.54, p<.01)$. But total numeracy skills of early childhood preservice teachers had a significant negative correlation with emotionality $(r=-.17, p=.002)$, worry $(r=-$ $.16, p=.005)$, and total mathematics anxiety $(r=-.18, p=.001)$. Other significant negative and positive correlations among numeracy skills, mathematics anxiety and mathematical beliefs of early childhood pre-service teachers can be gleaned from Table 3 below.

Table 3. Correlations matrix for the relationship between numeracy skills and its dimensions, mathematical beliefs and its dimensions and early childhood pre-service teachers' mathematics anxiety and its dimensions

\begin{tabular}{|c|c|c|c|c|c|c|c|c|c|c|c|}
\hline 1 & 2 & 3 & 4 & 5 & 6 & 7 & 8 & 9 & 10 & 11 & 12 \\
\hline \multicolumn{12}{|l|}{ 1. NUT 1} \\
\hline 2. NUE .76* & 1 & & & & & & & & & & \\
\hline 3. NWP .79* & $.39 *$ & 1 & & & & & & & & & \\
\hline 4. NMT .80* & $.40 *$ & $.47 *$ & 1 & & & & & & & & \\
\hline 5. $\mathrm{ABE} .37 *$ & $.29 *$ & $.30 *$ & $.29 *$ & 1 & & & & & & & \\
\hline 6. CBP $.37 *$ & $.21 *$ & $.37 *$ & $.29 *$ & $.23 *$ & 1 & & & & & & \\
\hline 7. MB . $41 *$ & $.35^{*}$ & $.35^{*}$ & $.28 *$ & $.20 *$ & $.26 *$ & 1 & & & & & \\
\hline 8. BMP .28* & .07 & $.30 *$ & $.27 *$ & $.20 *$ & $.26 *$ & $.34 *$ & 1 & & & & \\
\hline 9. MBT .54* & $.35^{*}$ & $.50 *$ & $.42 *$ & $.58^{*}$ & $.64 *$ & $.72 *$ & $.69 *$ & 1 & & & \\
\hline 10. EMO -. $17 *$ & .05 & $-.24 *$ & $-.21 *$ & $-.20 *$ & .08 & .023 & .006 & -.03 & 1 & & \\
\hline 11. WOR -.16* & .07 & $-.25^{*}$ & $-.18 *$ & -.11 & -.07 & .096 & .030 & -.008 & $.64^{*}$ & 1 & \\
\hline 12. MAT -.18* & .07 & $-.27 *$ & $-.22 *$ & $-.16^{*}$ & .003 & .068 & .021 & -.02 & $.90 *$ & $.92 *$ & 1 \\
\hline Mean $\quad 3.07$ & 3.38 & 2.89 & 2.93 & 2.91 & 2.60 & 2.89 & 2.75 & 2.79 & 2.03 & 2.19 & 2.11 \\
\hline 0.61 & 0.77 & 0.77 & 0.81 & 0.73 & 0.74 & 0.93 & 0.81 & 0.53 & 0.87 & 0.96 & 0.83 \\
\hline
\end{tabular}

*Correlation is significant at the .01 level (2-tailed). Note that NUT=numeracy total, NUE=numeracy in everyday task, NWP=numeracy in workplace tasks, NMT=numeracy in mathematical tasks, $\mathrm{ABE}=$ affective and behavioural engagement in mathematical learning, $\mathrm{CBP}=$ confidence and beliefs regarding one's personal competence in math, $\mathrm{MB}=$ mathematical beliefs, $\mathrm{BMP}=$ beliefs about mathematical problem solving, $\mathrm{MBT}=$ mathematical beliefs total, $\mathrm{EMO}=$ emotionality, WOR=worry, and MAT=mathematics anxiety total.

\subsection{Research Question Four: What are the composite and relative contributions of each factor of beliefs about math (affective and behavioural engagement in mathematical learning, confidence and beliefs regarding one's personal competence in math, mathematical beliefs, and beliefs about mathematical problem solving) and each factor of mathematics anxiety (emotionality and worry) to the explanation of the variance in the early childhood pre-service teachers' numeracy skills?}

The results in Table 4 below showed that the independent variables (affective and behavioural engagement in mathematical learning (ABE), confidence and beliefs regarding one's personal competence in math (CBP), mathematical beliefs (MB), beliefs about mathematical problem solving (BMP), emotionality (EMO) and worry (WOR)) jointly contributed a coefficient of multiple regression of .583 and a multiple correlation square of .340 to the prediction of early childhood pre-service teachers' numeracy skills. By implication, $34.0 \%$ of the total variance of the dependent variable (numeracy skills) was accounted for by the combination of the six independent variables. The results further revealed that the analysis of variance of the multiple regression data produced an $F$-ratio value significant at 0.001 level $\left(F_{(6,313)}=26.82 ; p<.001\right)$.

The results of the relative contributions of the independent variables to the prediction of early childhood pre-service teachers' numeracy skills was that mathematical beliefs was the most potent significant positive contributor to the prediction of early childhood pre-service teachers' numeracy skills $(\beta=.30$, $t=5.90, p=.000$ ), while affective and behavioural engagement in mathematical learning made the next significant positive contribution to the prediction of the dependent variable $(\beta=.22, t=4.48, p=.000)$. Confidence and beliefs regarding one's personal competence in mathematics made the next significant positive contribution to the prediction of the dependent variable $(\beta=.22, t=4.41, p=.000)$. Beliefs about mathematical problem solving ( $\beta=.08, t=1.50, p=.13)$, emotionality $(\beta=-.10, t=-1.58, p=.12)$, and worry $(\beta=-.09, t=-1.39, p=.17)$ did not make any significant negative or positive contribution to the prediction of early childhood pre-service teachers' numeracy skills. According to the standardized 
coefficients the regression model is as follows: Numeracy skills predicted $_{1}=1.58+0.22 \mathrm{ABE}+0.22 \mathrm{CBP}+$ $0.30 \mathrm{MB}+0.08 \mathrm{BMP}-0.10 \mathrm{EMO}-0.09 \mathrm{WOR}$.

Table 4. Model summary, coefficient and t-value of multiple regression analysis of mathematics anxiety dimensions, mathematical beliefs dimensions, and the outcome measure (numeracy skills)

\begin{tabular}{|c|c|c|c|c|c|}
\hline $\begin{array}{l}\text { Model summa1 } \\
\text { Multiple } \mathrm{R}=.5 \\
\text { Multiple } \mathrm{R}^{2}=. \\
\text { Multiple } \mathrm{R}^{2}(\mathrm{~A} \\
\text { Standard Error } \\
F_{(6,313)}=26.82 \text {, }\end{array}$ & $\begin{array}{l}0 \\
\text { usted })=.327 \\
\text { Estimate }=.5( \\
p<.001\end{array}$ & & & & \\
\hline Model & $\begin{array}{c}\text { Unstandardiz } \\
\text { B } \\
\end{array}$ & $\begin{array}{l}\text { oefficients } \\
\text { Std Error }\end{array}$ & $\begin{array}{c}\text { Standardized coeff. } \\
\text { Beta }\end{array}$ & $\mathrm{t}$ & Sig \\
\hline Constant & 1.58 & .18 & & 9.03 & .000 \\
\hline $\mathrm{ABE}$ & .19 & .04 & .22 & 4.48 & .000 \\
\hline CBP & .18 & .04 & .22 & 4.41 & .000 \\
\hline MB & .20 & .03 & .30 & 5.90 & .000 \\
\hline BMP & .06 & .04 & .08 & 1.50 & .134 \\
\hline EMO & -.07 & .04 & -.10 & -1.58 & .115 \\
\hline WOR & -.05 & .04 & -.09 & -1.39 & .167 \\
\hline
\end{tabular}

Note that $\mathrm{ABE}=$ affective and behavioural engagement in mathematical learning, $\mathrm{CBP}=$ confidence and beliefs regarding one's personal competence in math, $\mathrm{MB}=$ mathematical beliefs, $\mathrm{BMP}=$ beliefs about mathematical problem solving, $\mathrm{EMO}=$ emotionality, and WOR=worry.

\section{Discussion}

Majority of the early childhood pre-service teachers in this study had high mathematics anxiety $(N=178$ (55.63\%), Mean=2.72, SD=0.50) while $138(43.13 \%)$ of the early childhood pre-service teachers showed low mathematics anxiety (Mean $=1.33, S D=0.43$ ) and only 4 representing $1.24 \%$ of the early childhood pre-service teachers had moderate mathematics anxiety (Mean=2, $S D=0.00$ ). The high mathematics anxiety in the entire sample might be a result of their previous debilitating engagement with mathematics. It has been established that majority of Nigerian students showed high level of mathematics anxiety (Awofala \& Odogwu, 2017) and this might not be unconnected to their undesirable attitude transferred from their teachers, intellectual factors, and past failure in mathematics (Lindskog, Winman, \& Poom, 2017). Majority of secondary school students showed poor performance in mathematics (Awofala, 2017) and mathematics anxiety has been fingered as a possible cause (Awofala, 2008) aside poor teaching methodology (Awofala, Arigbabu \& Awofala, 2013) and negative attitudes towards mathematics (Awofala, 2016). In the present study, a large proportion of the early childhood pre-service teachers had high mathematical beliefs $(N=292(91.25 \%)$, Mean $=2.89, S D=0.43)$ while 26 $(8.13 \%)$ of the early childhood pre-service teachers showed low mathematical beliefs (Mean=1.68, $S D=0.22$ ) and only 2 representing $0.63 \%$ of the early childhood pre-service teachers had moderate mathematical beliefs (Mean $=2, S D=0.00$ ). The high mathematical beliefs of the early childhood preservice teachers indicated that they have their personal beliefs when it comes to the issue of mathematics teaching and learning as all of them were at one time or the other had experience with mathematics as students at the pre-tertiary levels. This high mathematical beliefs also showed the unique importance of mathematics activities in schools. This high mathematical beliefs corroborated the finding of GómezChacón, García-Madruga, Rodríguez, Vila, and Elosúa (2011) in which they found that high school science students in Spain had high mathematical beliefs.

The result of significant correlation between mathematical beliefs and numeracy obtained in this study showed that there is a direct positive association between numeracy and mathematical beliefs. The negative correlation between numeracy and mathematics anxiety attests to the assertion that there is an inverse relationship between numeracy and mathematics anxiety. In short, both dimensions (worry and emotionality) of mathematics anxiety had a negative correlation with total numeracy skills in this study. So, the higher the numeracy skills of early childhood pre-service teachers, the higher their mathematical beliefs and the lower their mathematics anxiety.

The results obtained in Table 4 above showed that $34 \%$ of the variance in early childhood pre-service teachers' numeracy skills was accounted for by the six predictor variables (affective and behavioural 
engagement in mathematical learning, confidence and beliefs regarding one's personal competence in math, mathematical beliefs, beliefs about mathematical problem solving, emotionality, and worry) taken together while $66 \%$ of the variance in numeracy skill could not be substantiated by the current data. This showed that there might be other independent variables which may require further investigations about their contribution to the prediction of early childhood pre-service teachers' numeracy skills. That mathematical beliefs predicted early childhood pre-service teachers numeracy skills agreed with the finding of Gómez-Chacón et al (2011) who found that mathematical beliefs predicted students' achievement in mathematics.

\section{Conclusion}

This present study has underscored particularly thought-provoking conundrums when looking at the associations involving early childhood pre-service teachers' numeracy skills, mathematical beliefs, and mathematics anxiety. Although the associations between numeracy skills and mathematical beliefs are positive, direct, and striking, of more interest is the dependability of the negative association of mathematics anxiety to numeracy skills of early childhood pre-service teachers. Thus, the higher the mathematics anxiety, the lower the numeracy skills of early childhood pre-service teachers. While mathematics anxiety did not predict early childhood pre-service teachers' numeracy skills, it is important to note that mathematics anxiety had a negative correlation with numeracy skills. This latter result shows the need to reduce early childhood pre-service teachers' mathematics anxiety as this could interfere in their teaching of mathematics in schools. Appropriate instructional pedagogies capable of reducing or eliminating fear of mathematics in early childhood pre-service teachers should be applied to teaching them and foster constructivist mathematical beliefs. This is important because teachers who have fear for mathematics have been known to transfer their mathematics anxiety to their students (Awofala \& Akinoso, 2017). Educators need to provide an enabling environment free of mathematics anxiety for early childhood pre-service teachers as they engage in the learning of mathematics they will be required to teach. The paucity of research on mathematics anxiety and mathematical beliefs as correlates of numeracy skills among early childhood pre-service teachers showed the need for stakeholders in the research community to engage in this fruitful endeavour to further generalize the findings of this study. In conclusion, early childhood teacher education programme in Nigeria should include strategies to eliminate mathematics anxiety and foster constructivist mathematical beliefs capable of promoting early childhood pre-service teachers' numeracy skills.

\section{Bibliography}

Aschraft, M. H. \& Moore, A. M. (2009): Mathematics anxiety and the affective drop in performance. Journal of Psychoeducation Assessment, 27(3), 197-205.

Ashcraft, M. H, \& Faust, M. W. (1994): Mathematics anxiety and mental arithmetic performance: An exploratory investigation. Cognitive Emotion, 8(2), 97-125.

Aslan, D., Ogul, I. G. \& Tas, I. (2013): The impacts of preschool teachers' mathematics anxiety and beliefs on children's mathematics achievement. International Journal of Humanities and Social Science Invention, 2(7), 45-49.

Awofala, A. O. A. \& Akinoso, S. O. (2017): Assessment of psychometric properties of mathematics anxiety questionnaire by preservice teachers in south-west, Nigeria. ABACUS: The Journal of the Mathematical Association of Nigeria, 42(1), 355-369.

Awofala, A. O. A. \& Anyikwa, B. E. (2014): Assessing adult learners' numeracy as related to gender and performance in arithmetic. New Approaches in Educational Research, 3(2), 83-92. DOI: 10.7821/naer.3.2.83-92.

Awofala, A. O. A. \& Awolola, S. A. (2011): The effect of self-efficacy, anxiety, attitude, and previous mathematics achievement on senior secondary students' performance mathematics. African Journal of Historical Sciences in Education, 7(2), 198 - 209 
Awofala, A. O. A. \& Odogwu, H. N. (2017): Assessing preservice teachers' mathematics cognitive failures as related to mathematics anxiety and performance in undergraduate calculus. Acta Didactica Napocensia, 10(2), 81 - 97.

Awofala, A. O. A. (2016): Examining preservice mathematics teachers' attitudes toward mathematics. Nigerian Journal of Curriculum Studies, 23, 292-300.

Awofala, A. O. A. (2017): Assessing senior secondary school students' mathematical proficiency as related to gender and performance in mathematics in Nigeria. International Journal of Research in Education and Science, 3(2), 488-502.

Awofala, A. O. A., Arigbabu, A. A. \& Awofala, A. A. (2013): Effects of framing and team assisted individualised instructional strategies on senior secondary school students' attitudes toward mathematics. Acta Didactica Napocensia, 6(1), 1 - 22.

Beswick, K. (2005): It depends on the students: Influencing teacher beliefs about the ends and means of numeracy teaching. In P. Clarkson, A. Downton, D. Gronn, M. Horne, A. McDonough, R. Pierce, \& A. Roche (Eds.), Building connections: Research, theory and practice (Proceedings of the 28th annual conference of the Mathematics Education Research Group of Australasia, Vol. 1, pp. 137-144). Sydney: MERGA.

Brown, C. A. (1986): The study of the socialization to teaching of a beginning secondary mathematics teacher. Doctoral dissertation, University of Georgia, Dissertation Abstracts International, 46, 2605-A.

Butterworth, B. (2010): Foundational numerical capacities and the origins of dyscalculia. Trends in Cognitive Science, 14, 534-541.

Cokely, E. T., Galesic, M., Schulz, E., Ghazal, S. \& Garcia-Retamero, R. (2012): Measuring risk literacy: The Berlin numeracy test. Judgment Decision Making, 7(1), 25-47.

Denton, K., \& West, J. (2002): Children's reading and mathematics achievement in kindergarten and first grade. Education Statistics Quarterly, 4, 19-26.

Ernest, P. (1991): The philosophy of mathematics education. London: Falmer Press.

Geist, E. (2015): Math anxiety and the "math gap": How attitudes toward mathematics disadvantages students as early as preschool. Education, 135(3), 328-336.

Gómez-Chacón, I. M., García-Madruga, J. A., Rodríguez, R., Vila, J. Ó., \& Elosúa, M. R. (2011): Mathematical beliefs and cognitive reflection: Do they predict academic achievement? Current state of research on Mathematical beliefs XVII Roesken, B. \& Casper, M. (Ed.) (Pg. 64-73). Proceedings of the MAVI-17 Conference, September 17-20, 2011, Bochum, Germany.

Gómez-Chacón, I.Ma \& García-Madruga, J. A. (2009): Mathematical beliefs questionnaire (Creemat). In I+D+i project: Cognition and education: working memory, reading comprehension and reasoning, from the Spanish Ministry of Science and Innovation.

Heinkle, D. (2000): School Involvement in Early Childhood. U.S. Department of Education, National Institute for Early Childhood Development and Education. Washington, DC: U.S. Government Printing Office.

Kagan, D. M. (1992): Implication of research on teacher belief, Educational Psychologist, 27(10), 6590 .

Kane, R., Sandretto, S., \& Heath, C. (2002): Telling half the story: A critical review of research on the teaching beliefs of university academics. Review of Educational Research, 72(2), 177-228.

Karatas, I., Guven, B., Öztürk, Y., Arslan, S. \& Gürsoy, K. (2017): Investigation of pre-school teachers' beliefs about mathematics education in terms of their experience and structure of their education. Eurasia Journal of Mathematics Science and Technology Education, 13(3), 673-689. DOI 10.12973/eurasia.2017.00638a.

Kucian, K. \& von Aster, M. (2015): Developmental dyscalculia. European Journal of Pediatrics, 174, $1-13$. 
Kupari, P. (2003): Instructional practices and teachers"e beliefs in Finnish mathematics education. Studies in Educational Evaluation, 29, 243-257.

Lake, V. E. \& Kelly, L. (2014): Female preservice teachers and mathematics: Anxiety, beliefs, and stereotypes. Journal of Early Childhood Teacher Education, 35(3), 262-275, DOI: 10.1080/10901027.2014.936071.

Lindskog, M., Winman, A, \& Poom, L. (2017): Individual differences in nonverbal number skills predict math anxiety. Cognition, 159, 156-162.

Maloney, E. A., Ansari, D., \& Fugelsang, J. A. (2011): The effect of mathematics anxiety on the processing of numerical magnitude. Quarterly Journal of Experimental Psychology, 64(1), 10-16.

Mertler, C. A., \& Charles, C. M. (2005). Introduction to educational research (5Th Ed) Boston: Pearson

National Association for the Education of Young Children. (2001): NAEYC standards for early childhood professional preparation. Washington, DC: Author.

National Council of Teachers of Mathematics. (2000): Principles and standards for school mathematics. Reston, VA: National Council of Teachers of Mathematics.

OECD. (2011), Starting Strong III: A Quality Toolbox for Early Childhood Education and Care, OECD Publishing, Paris. DOI: http://dx.doi.org/10.1787/9789264123564-en.

OECD. (2015), Starting strong IV: Monitoring quality in early childhood education and care. OECD Publishing, Paris. DOI: http://dx.doi.org/10.1787/97826423315-en.

Owens, L. K. (2002): Introduction to survey research design. SRL Fall 2002 Seminar Series http://www.srl.uic.edu

Parsons, S. \& Bynner, J. (2005). Does numeracy matter more? London: National Research and Development Centre for adult literacy and numeracy.

Paulos, J. A. (1988): Innumeracy: Mathematical illiteracy and its consequences. New York: Vintage Books.

Peters, E. (2012). Beyond comprehension: The role of numeracy in judgments and decisions. Current Direction in Psychological Science, 21(1), 31-35.

Peters, E. Västfjäll, D., Slovic, P., Mertz, C. K., Mazzocco, K. \& Dickert, S. (2006): Numeracy and decision making. Psychological Science, 17(5), 407-413.

Peterson, P. L. Fennema, E. Carpenter, T. P. \& Loef, M. (1989). Teachers' pedagogical content beliefs in mathematics, Cognition and Instruction, 6, 1989, 1-40.

Raymond, A. M. (1997): Inconsistency between a beginning elementary school teacher's mathematics beliefs and teaching practice. Journal for Research in Mathematics Education, 5, 550-576.

Reyna, V., Nelson, W. L., Han, P. K. \& Dieckman, N. F. (2009). How numeracy influences risk comprehension and medical decision making. Psychology Bulletin, 135(6), 943-973.

Richardson, F. C. \& Suinn, R. M. (1972): The mathematics anxiety rating scale: Psychometric data. Journal of Counselling Psychology, 19(6), 551-554.

Schwartz, L. M., Woloshin, S., Black, W. C. \& Welch, H. G. (1997). The role of numeracy in understanding the benefit of screening mammography. Annal of Internal Medicine, 127(11), 966-972.

Skagerlund, K., Östergren, R., Västfjäll, D, \& Träff, U. (2019): How does mathematics anxiety impair mathematical abilities? Investigating the link between math anxiety, working memory, and number processing. PLoS ONE 14(1): e0211283. https://doi.org/10.1371/journal.pone.0211283

Stipek, D. J. Givvin, K. B., Salmon, J. M. \& MacGyvers, V. L. (2001): Teachers' beliefs and practices related to mathematics instruction. Teaching and Teacher Education, 17, 213-226. 
Suárez-Pellicioni, M., Núñez-Peña, M. I., \& Colomé, A. (2016): Math anxiety: A review of its cognitive consequences, psychophysiological correlates, and brain bases. Cognitive and Affective Behavioural Neuroscience, 16(1), 3-22. DOI: 10.3758/s13415-015-0370-7.

Weller, J., Dieckmann, N. F., Tusler, M., Mertz, C. K, Burns, W. J. \& Peters, E. (2013): Development and testing of an abbreviated numeracy scale: A Rasch analysis approach. Journal of Behavioural Decision Making, 26(2), 198-212.

Yesil-Dagli, U. Lake, V. E. \& Jones, I. (2010): Preservice teachers' perceptions towards mathematics and science. Journal of Research in Education, 20(2), 32-48.

Zakaria, E. \& Maat, S. M. (2012): Mathematics teachers' beliefs and teaching practices. Journal of Mathematics and Statistics, 8(2), 191-194.

\section{Authors}

Oludola S. Sopekan, University of Lagos, Akoka (Nigeria). E-mail: osopekan@ unilag.edu.ng.

Adeneye O. A. Awofala, University of Lagos, Akoka (Nigeria). E-mail: aawofala@unilag.edu.ng 